\title{
Linking Sustainability to Quality Management and Firm Performance
}

\author{
Rajat Mishra ${ }^{1} \&$ Randy Napier ${ }^{2}$ \\ ${ }^{1}$ Nelson Rusche College of Business, Stephen F. Austin State University, Nacogdoches, Texas, USA \\ ${ }^{2}$ College of Business, University of Texas at Arlington, Arlington, Texas, USA \\ Correspondence: Randy Napier, College of Business, University of Texas at Arlington, Arlington, TX 76019, \\ USA. Tel: 1-817-272-3502. E-mail: rnapier@uta.edu
}

Received: November 10, 2014

Accepted: January 4, 2015

Online Published: February 27, 2015

doi:10.5539/ijbm.v10n3p1

URL: http://dx.doi.org/10.5539/ijbm.v10n3p1

\begin{abstract}
Environmental management practices have evolved significantly over the past two decades. During that time, sustainable operations management practices have purportedly made positive contributions to overall firm performance. This paper develops two conceptual frameworks regarding the relationships among specific elements of environmental management, quality management, and firm performance. We suggest that innovation in quality management mediates the relationship between design for environment and firm performance, and that statistical process control techniques moderate the relationship between environmental management systems and firm performance. We identify future research possibilities, based on these frameworks, to inform scholarly research and practice in environmental management and quality management.
\end{abstract}

Keywords: design for environment, environmental management systems, firm performance, quality management, sustainability

\section{Introduction}

Over the past two decades, the treatment of environmentally responsible practices in operations management literature has evolved from its initial status as a novelty to become a mainstay of research in the field. Elkington (1997) predicted that "the sustainable capitalism transition" would be a very complex transition.

This transition is, in fact, a work in progress. Enhanced attention to broader issues of social responsibility has heightened awareness of, and interest in, research in sustainable operations and related management practices. As an example, Laroche, Bergeron and Barbaro-Forleo (2001) found that consumers in certain demographic groups are willing to pay more for products produced in an environmentally responsible way.

Organizations that have implemented environmentally responsible management practices have reported success. Examples include Kimberly Clark (McDermott, 1995), and 3M Companies with their Pollution Prevention Pays (3P) program (Codington, 1993). Reflecting on this, Chandrashekar, Dougless and Avery (1999) observed that well-devised and carefully controlled environmental programs pay for themselves and so are "free." Nevertheless, research on the underlying relationships among specific elements of environmental management and quality management is relatively scarce. And research examining firm performance effects that flow from those relationships is also scarce. This paper is an initial step in a broader effort to fill those gaps.

More specifically, we present two conceptual frameworks dealing with the relationships among specific elements of environmental management, quality management, and firm performance. The first of these addresses the relationship between design for environment and firm performance, with quality innovation mediating this relationship. The second framework considers the relationship between environmental management systems and firm performance, with the application of statistical process control techniques having a moderating effect. We begin with a review of relevant foundation literature, develop the conceptual frameworks, and discuss the contribution and potential future extensions of this research.

The remainder of this paper is organized as follows. Section 2 discusses foundation research in sustainable operations, quality management, and the effect of operational initiatives on firm performance. Section 3 presents the two conceptual frameworks that link environmental management to quality management and firm performance. Section 4 discusses the contributions and potential future extensions of this research. Section 5 
offers concluding remarks and discusses the implications of this study for future research and management practice in sustainable operations.

\section{Foundations: Sustainable Operations, Quality Management, and Firm Performance}

Research in operations management as a distinct academic discipline began with publication of the Journal of Operations Management in 1980, although other journals such as the International Journal of Production Economics had published peer-reviewed research on production management and economics as far back as 1976. Early papers by Buffa (1980) and Chase (1980) plotted the course for early research in operations management.

Environmental management and related topics have garnered increasing attention in operations management journals in recent years (e.g., Beske, Land, \& Seuring, 2014). This reflects changing social norms as well as pressure from government entities, advocacy groups, and consumers. Environmental responsibility and environmental management topics are often referenced within the broader field of operations management under the label of sustainable operations (Elkington, 1994).

\subsection{Sustainable Operations}

Sustainable operations, otherwise known as green operations or sustainability, are defined in diverse ways by various scholars. Kleindorfer, Singhal and Van Wassenhove (2005) defined the term sustainability as "environmental management, closed loop supply chains and a broad perspective on triple bottom line thinking, integrating profit, people and the planet into the culture, strategy, and operations of companies." A frequently cited definition is used by Brundtland (1987), Daly and Cobb (1994), and Linton, Klassen and Jayaraman (2007). These works define sustainability as using the resources of the present without compromising the ability of future generations to meet their own needs.

Guide and Van Wassenhove (2009) define sustainable operations as the design, control, and operation of a system to maximize value creation with dynamic recovery of value. Elkington (1994) coined the phrase triple bottom line to encompass social, environmental and economic aspects in a balanced and proportionate manner, and this framework has become widely accepted. Sustainability can be defined as the design, management, and improvement of a company's business processes to positively impact society, the economic performance of the firm, and the physical environment. Under this view, it becomes important to incorporate environmentally responsible practices into all aspects of operations management.

The broad topic of sustainable operations has many dimensions. Aspects of sustainable operations that are relevant to the models presented in this paper are environmental management systems and design for environment (DFE). Foundation research in each of these areas is considered below.

\subsubsection{Environmental Management Systems}

Researchers often find it useful to view the set of processes used to implement sustainable operations practices as a system. Guide and Van Wassenhove (2009) define closed-loop supply chain management as involving "a system to maximize value creation over the entire life cycle of a product with dynamic recovery of value from different types and volumes of returns over time."

The International Standards Organization's ISO 14000 standards (ISO 14000) deal with diverse facets of environmental management. ISO 14000 provides companies with a framework and tool set for evaluating and minimizing the environmental impact of their operations, and for pursuing continuous improvement in environmental performance (International Standards Organization, 2014b). The ISO 14001:2004 and ISO 14004:2004 standards are devoted to environmental management systems. Researchers often use ISO 14000 certification as the criterion for identifying firms that have implemented environmental management systems (Montabon, Melnyk, Sroufe, \& Calantone, 2000; Vastag \& Melnyk, 2002; Melnyk, Sroufe, \& Calantone 2003). This approach is consistent with that taken by earlier researchers in using quality awards to identify firms that have successfully implemented TQM (Hendricks \& Singhal, 2001a, 2001b).

Prior research has investigated the environmental performance and firm performance effects of environmental management systems, but has not considered the interaction of EMS with quality management practices (Montabon, Melnyk, Sroufe, \& Calantone 2000; Link and Naveh 2006; González-Benito and González-Benito 2008; Heras-Saizarbitoria, Molina-Azorín, \& Dick 2011; Comoglio \& Botta 2012).

\subsubsection{Design for Environment}

Design for environment (DFE) is a technique that has gained increased attention in recent years. Under DFE, environmental considerations are explicitly recognized and incorporated in product and process design. DFE is intended to ensure that all relevant and ascertainable environmental considerations and constraints are integrated 
into the firm's design process (Allenby, 1994). During the formative phase of DFE, the design and implementation of processes was often abstract and imprecise (Boks \& Stevels, 2007).

More recently, DFE is considered to have matured; this view is supported by Boks and Stevels (2007) where we "....have all the procedures in place, have considerable experience, [and] have recurring problems with embedding environmental issues in the organization and its value chain." DFE embodies the philosophical view that environmental considerations must be integrated into the design of any product or process at the inception of the design phase. Sarkis (1998) noted that a number of functional sub-components should be included in a successful DFE program; these include recyclability, re-manufacturability, reuse, disassembly and disposal. DFE also includes consideration of technological parameters and organizational relationships (Allenby 1994).

Research on DFE in operations management and related fields has focused on implementation frameworks and acceptance of the technique - with minimal attention devoted to measuring the performance effects of DFE. Veroutis and Aelion (1996) offer a framework for implementing DFE, but do not offer empirical evidence regarding performance effects. Sarkis (1998) develops an analytical network process (ANP) model to support decisions regarding the adoption of environmentally-responsible management practices, including DNP.

Others offer case studies that address organizational factors affecting DFE adoption without generalizable findings on the performance effects of DFE. Examples include Sroufe, Curkovic, Montaban, and Melnyk (2000); Lenox and King (2000); Ernzer and Wimmer (2002); and Boks and Stevels (2007). In addition to minimal consideration of performance effects, prior research on DFE has not specifically addressed quality innovation as a factor in the successful implementation of DFE.

With the overview of environmental management systems and design for environment complete, it is appropriate to turn to quality management principles - with emphasis on quality innovation and statistical process control.

\subsection{Quality Management}

Quality management is generally regarded as a broad sub-discipline of operations management (see, e.g., Krajewsky, Ritzman, \& Malhotra, 2010). Many quality-centric firms embrace the Total Quality Management (TQM) approach and/or pursue ISO 9000 certification. TQM is a customer-focused approach aimed at meeting or exceeding customer expectations with regard to products or services, and is often viewed as a philosophy or a company-wide strategy rather than a segmented or piecemeal tool set (Feigenbaum, 1983). ISO 9000 certification signifies adherence to quality management standards maintained by the International Standards Organization. This family of standards provides guidance and tools for organizations to ensure that their products and services consistently meet customer requirements, and that quality is consistently improved over time (International Standards Organization, 2014a).

Prevention of defects is a foundation principle of TQM, and the ultimate target in that regard is defect-free operation (Feigenbaum, 1983). TQM has been defined as a process and philosophy for achieving optimal results from process inputs to deliver value to the customer, while also achieving the long-term objectives of the enterprise (Feigenbaum, 1983).

Defect minimization has become a basic requirement in many industries. This has spurred the evolution of quality management practices from the tradition of simple, reactive, and inspection-based quality control approaches to the strategically-focused TQM programs that are prevalent today (Matias \& Coehlo, 2002). Many organizations that embrace the TQM philosophy also pursue ISO 9000 certification (Matias, 1999). TQM has spread from its historical base in manufacturing operations to the service sector, and this includes some government entities (Dale 2003). A common theme of the works cited above is that TQM can be a source of competitive advantage or a key driver of strategic success.

Elements of TQM that may be specifically relevant to sustainable operations include statistical process control and quality innovation. Foundation research on these topics is discussed next.

\subsubsection{Statistical Process Control}

Statistical Process Control (SPC) is one of the process management techniques that comprise TQM practice. SPC applies statistical methods to monitor and control a process. The objective of SPC is to ensure that the process operates at its full potential to consistently produce conforming product (Feigenbaum, 1983). In a manufacturing setting, SPCis intended to maximize the output of conforming product while minimizing waste.

While SPChas been applied most frequently to control in manufacturing processes, it can be applied to any process with a measurable output. Oakland (2003) defined SPC as a strategy for reducing variability. SPC must be planned appropriately with operations managers, engineers, and front-line employees to achieve long term 
profitability. SPC can detect the existence of problems in the early stages of a process to facilitate prompt corrective action, and is often preferable to qualitative techniques like general inspection. SPC can reduce the amount of rework required while reducing cycle times and lead times, leading to significant overall process improvement (Oakland, 2003).

Given the widespread application of SPC, published research on the performance effects of SPC is surprisingly scarce in operations management and related fields. Swamidass and Majerus (1991) conducted a single-site case study and found that SPC implementation successfully reduced manufacturing cycle times. Sower (1993), investigated the plastic molding industry in Texas and found a positive relationship between SPC implementation and improved process performance.

Other researchers have tacitly assumed that SPC enhances process performance, and have focused on methodologies for implementing SPC (Chen, Yang, Lin, \& Yeh, 2008) or for evaluating the effectiveness of SPC tools and techniques (Colledani \& Tolio, 2009; Ou, Wu, \& Tsung, 2012) without empirically measuring the operational performance or firm performance effects of SPC. Coleman, Arunakumar, Foldvary, and Feltham (2001) offer a structured implementation methodology for using SPC with selected metrics to improve performance in a variety of processes, and detail the results of applying their methodology in a single-site case study.

Corbett and Pan (2002) offer a process for using SPC and capability indices to evaluate environmental performance, but do not empirically test the performance effects of the defined process. Wiengarten and Pagell (2012) refer to SPC in discussing the possibility that quality management techniques can interact with and enhance the success of environmental management practices, and include SPC as one of four elements of quality management in evaluating the quality management-environmental management interaction.

\subsubsection{Quality Innovation}

"Lean is green" is no longer a new phrase. Process improvements that flow from quality management innovation can reduce waste, which tends to reduce adverse environmental effects while yielding other operational advantages. Porter and van der Linde (1995) have observed that viewing pollution as resource inefficiency can be traced to the quality revolution of the 1980's. Similarly, Mannion (1996) and Pojasek (2002) suggest a logical relationship between environmental management and quality management. Other researchers have identified a trend toward convergence of quality management and environmental management (Hanna \& Newman, 1995; Klassen \& McLaughlin, 1993). Quality management initiatives that can be viewed as evidence of quality innovation include TQM implementation and adoption of the Six Sigma methodology to reduce defects and process variability.

In its formative phase TQM, and quality management practices in general, were considered risky and difficult to implement. TQM was used to signal to customers that the firm is committed to the timely delivery of products that are fit for the intended use. More recently, TQM has been regarded as consistent with cost minimization due to its tendency to reduce waste (Zhu \& Sarkis, 2004).

Over the years, TQM has come to represent more than the consumer perception of better quality. TQM has been recognized as a source of competitive advantage and an element of operational excellence. Samson and Terzioviski (1999) examined 1,200 Australian and New Zealand manufacturing organizations, evaluated reliability and validity, and found that the relationship between TQM and operational performance is significant. They also found that some categories of TQM practice were particularly strong predictors of operational performance-including leadership and customer focus. Hendricks and Singhal (1997, 2001a, 2001b) have identified a positive relationship between successful TQM implementation and firm performance. Thus the positive impact of quality innovation, as represented by TQM implementation, on operational performance is widely accepted.

The Six Sigma approach to process improvement is widely regarded as an important emerging aspect of quality management (Zu, Frendendall, \& Douglas, 2008). The Six Sigma methodology involves reliance on statistical techniques and structured problem-solving methods to improve process performance by minimizing the occurrence of defects and reducing process variability (Pande, Neuman, \& Cavanaugh, 2000). Six Sigma techniques were developed by Motorola Corporation in the 1980's (Denton 1991), and have subsequently been embraced by the General Electric Company and others (Lucier \& Seshadri, 2001; Brady, 2003).

Operations management literature includes empirical studies on the performance effects of Six Sigma methods. Goh, Low, Tsui, and Xie (2003) examined the stock price performance of companies implementing the Six Sigma methodology and found no evidence of above-normal returns versus the Standard \& Poor's 500 index. 
Shafer and Moeller (2012) studied the effect of Six Sigma adoption on corporate performance in terms of financial statement-based efficiency measures. These authors found evidence of improved efficiency in terms of employee productivity but not in terms of asset efficiency measures (Shafer \& Moeller, 2012).

Swink and Jacobs (2012) evaluated the operating performance of 200 Six Sigma-adopting companies and found significant reductions in indirect costs but no significant improvement in direct cost profiles or asset productivity Saghaei, Najafi, and Noorossana (2012) demonstrated the measurement of yield and rework to evaluate the performance effects of Six Sigma implementation in a single-site case study, but relied on internal and firm-specific data that would not typically be available in published financial statements. Calia, Guerrini, and de Castro (2009) studied the effectiveness of 2,096 pollution prevention projects, and found that improved pollution prevention is positively associated with the implementation of Six Sigma methods.

Thus, research that examines the effect of Six Sigma methods on firm performance to date has yielded mixed results. With the exception of Calia et al. (2009), none of these studies have considered Six Sigma impacts on environmental performance. And none of the cited papers has considered the effect of Six Sigma as a moderating variable on the firm performance effects of DFE.

Some researchers have considered the relationship of TQM and other forms of quality management innovation to sustainable operations in general terms. Klassen and McLaughlin (1996) note that quality management frameworks and environmental management practices are similar in many ways. Rusinko (2005) offers a phased process for leveraging quality management practices as a foundation for a sustainability initiative in a single-site case setting. Sroufe and Curkovic (2008) suggest that TQM is a useful foundation for the implementation of environmental management practices. Wiengarten and Pagell (2012) conducted an empirical study and determined that environmental management is positively associated with cost, flexibility, and delivery performance when investment in quality management practices is high. While these studies provide evidence that TQM and other forms of quality innovation are positively associated with successful sustainability initiatives, none of these explicitly addresses the relationship between DFE, quality innovation, and firm performance.

\subsection{Measuring Firm Performance}

Different measures of firm performance have been applied in research that examines environmentally responsible management practices. Some research relies on stock market price performance of shares in publicly-traded companies. Other researchers have used archival data from audited financial statements, and other methods have also been used to measure firm performance. Jacobs, Singhal, and Subramanian (2010) tracked stock price movements following announcements involving environmental management undertakings, recognition awards for environmental management, and environment-related certifications. Dowell, Hart, and Yeung (2000) used Tobin's $q$ to evaluate firm performance effects in multinational companies making resource commitments in developing countries.

The relationship between environmental management commitment and firm performance was examined by King and Lenox (2002); this study considers both return on investment (ROI) per published financial statements and Tobin's $q$ to measure firm performance. The impact of a marketing strategy that incorporates environmental responsibility was studied by Menon and Menon (1997), with these authors calling for firm performance measures that recognize both (a) increasing sales and profit, and (b) environmental and social performance.

Operations management literature on topics other than environmental management also provides useful examples of firm performance measures. Firm performance measures used in the context of the successful implementation of total quality management (TQM) initiatives include changes in operating income (Hendricks \& Singhal, 1997) and changes in operating income before depreciation, revenue growth, and the ratio of total revenue to total expenses (Hendricks \& Singhal, 2001a). Hendricks and Singhal have also turned to stock price movement to measure firm performance attributable to TQM initiatives (Hendricks \& Singhal, 2001b).

Operational ratios calculated from publicly-available financial statements were used to evaluate the relationship of outsourcing to firm performance by Jiang, Frazier, and Prater (2006). That study includes ratios grouped to represent efficiency (sales to expenses), productivity (total sales in proportion to asset classes and employee count) and profitability (return on assets and net profit margin).

\section{Theoretical Frameworks and Propositions}

With relevant literature on sustainability and quality management considered, it is appropriate at this point to present the theoretical frameworks and the related propositions. 


\subsection{Design for Environment, Quality Innovation, and Firm Performance}

It has been suggested that environmental management strategies pay for themselves (Chandrashekar et al., 1999) as they support improvement in quality management practices, which in turn improves operational efficiency. Handfield, Walton, Seegers, and Melnyk (1997) interviewed environmental managers in the furniture industry, and suggested that environmental management strategies must be integrated into all stages of the value chain-including processes spanning product design, procurement, manufacturing, packaging, logistics, and distribution.

Other researchers have also found that different elements of the value chain can be improved when environmental management strategies are implemented. Lenox, King \&Ehrenfeld (2000) found that a growing number of managers believe that addressing environmental impacts in product design decisions brings tangible advantages to firms, with the word "advantages" referring to improvement in quality. King and Lenox (2001) studied US manufacturing firms and found that those adopting the ISO 9000 quality management standard were more likely to also adopt the ISO 14000 environmental management standards.

Those authors also identified a latent positive relationship between design for environment and quality management practices. DFE impacts quality management, and leads defect reduction and continuous improvement. These practices are collectively embodied in Total Quality Environmental Management, or TQEM (Corbett \& Klassen, 2006). It is reasonable to expect that implementing DFE and other elements of TQEM would lead to higher firm performance.

A framework representing innovation in quality management practices mediating the relationship between DFE and operational efficiency at multiple levels is shown in Figure 1. This is an adaptation of a framework developed by Kitazawa and Sarkis (2000).

The framework in Figure 1 is grounded in the notion that corporate social responsibility and/or sustainable operations requirements imposed by stakeholders imply pressure to consider environmental effects during product and process design phases. Design engineers, operations managers, and others establish objectives and set measurable goals. The roles and responsibilities of staff members are defined with a view to achieving these goals. Staff members are trained to become efficient, competent, and capable of executing their assigned roles. The resulting processes are monitored by management, and corrective action can be taken when flaws become evident. Thus DFE can support improvement in products, processes and human resource management. This leads to improved process performance at many levels.

It is also reasonable to expect that firms with a history of successful innovation in quality management would more readily embrace DFE practices, and that such firms would also tend to be more successful in generating firm performance benefits from DFE implementation. Successful TQM initiatives, as evidenced by ISO 9000 certification, or the adoption of Six Sigma techniques could be regarded as positive evidence of quality management innovation. 


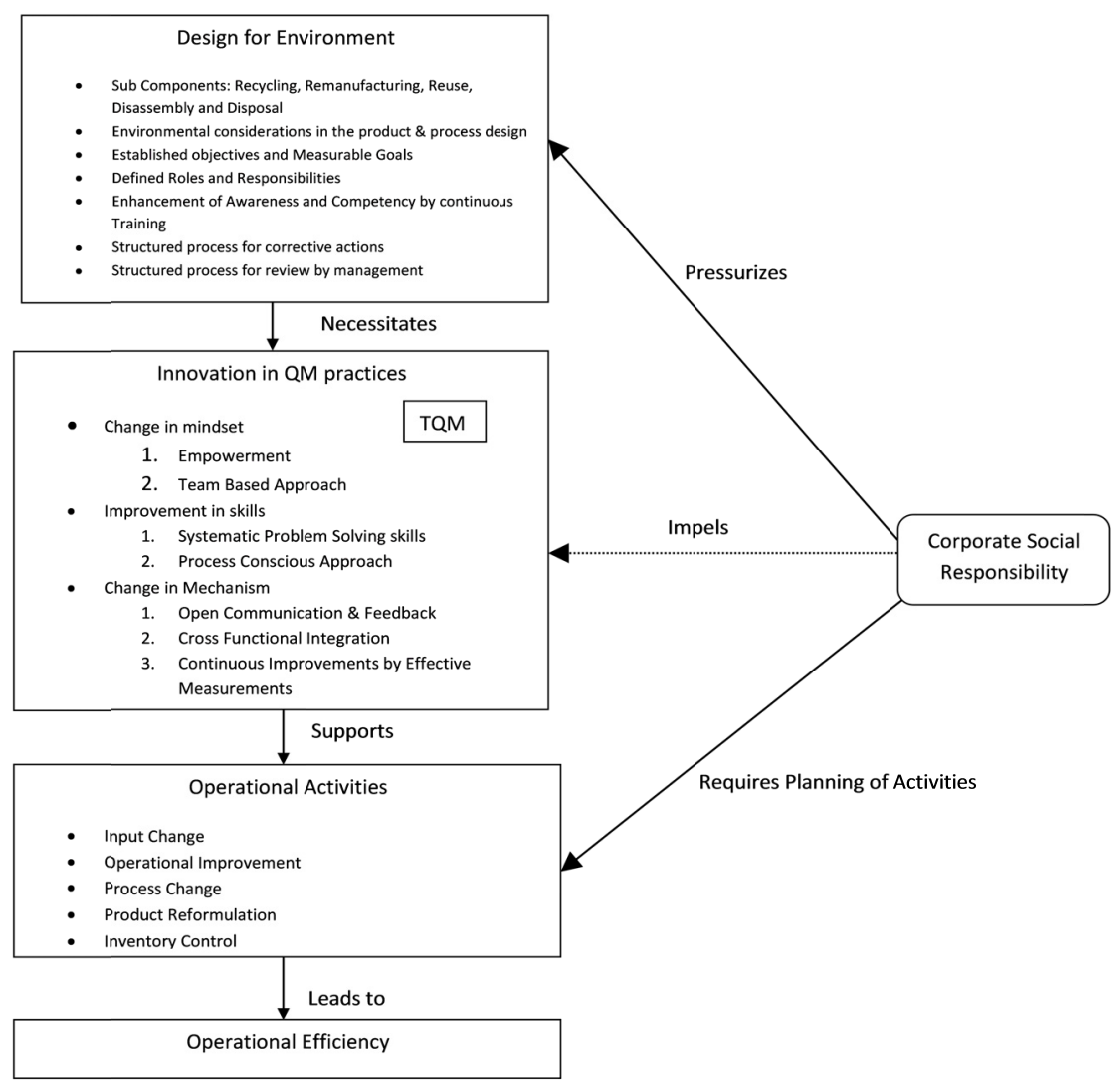

Figure 1. The motivating effect of corporate social responsibility

Source: The motivating effect of corporate social responsibility on DFE, quality management innovation, and operational efficiency (Adapted Kitazawa \&Sarkis, 2000).

Thus, it is reasonable to expect that DFE can support operational improvement through the elimination of waste, which would tend to improve firm performance. It is also reasonable to expect that DFE would be implemented through many of the structures and processes involved in quality management innovation, and that DFE would therefore be most readily and effectively implemented in firms that have embraced quality management innovation.

Further, it would be logical to expect that the effect of DFE on firm performance would be significantly affected by the firm's experience with quality management innovation. Under the framework developed by Baron and Kenny (1986) this would be a mediation effect.

This gives rise to the following propositions.

Proposition 1a: Design for environment is positively associated with firm performance.

Proposition 1b: Innovation in quality management practices mediates the relationship between design for environment and firm performance.

The relationships embodied in these propositions are shown schematically in Figure 2.

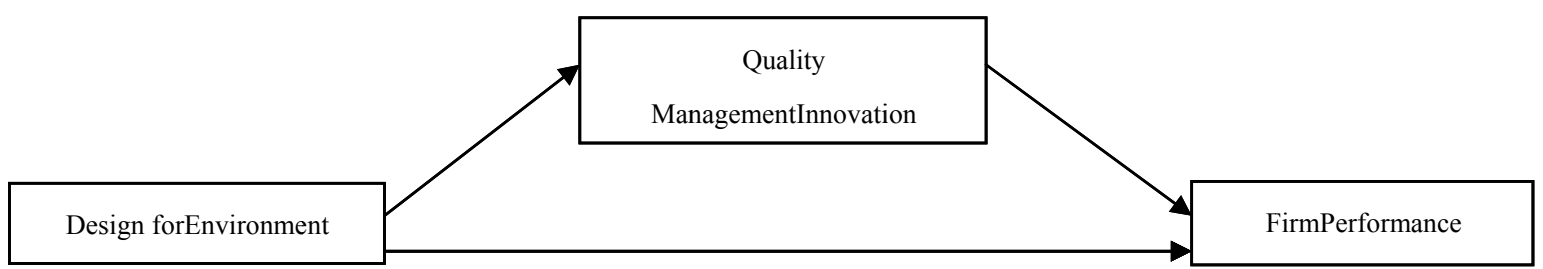

Figure 2. The mediating effect of quality management innovation 
Quality management innovation mediates the relationship between design for environment and firm performance.

\subsection{Environmental Management Systems, Statistical Process Control, and Firm Performance}

The evolution of terminology related to quality management has included quality control, TQM, and more recently total quality environmental management or TQEM (Corbett \& Klassen, 2006). TQEM entails a more holistic view of environmental management as an element of operations management. Under TQEM, the operations or business process elements of TQM are focused on economic performance gains, and the letter "E" in "TQEM" represents the environmental aspects.

Under this view, TQM and Environmental Management synergistically influence the operational performance of a firm. Improved operational performance may be visible in the long run, although it may not be immediately evident in the near term. Corbett and Klassen (2006) argued that developments are initially driven by practice, and that many benefits of adopting environmentally responsible practices were initially unexpected. Given that these unexpected benefits are frequently observed, those researchers refer to this phenomenon as the "law of the expected unexpected side benefits" (Corbett \& Klassen, 2006).This body of work supports the notion that adopting environmentally responsible management practices, as evidenced by the implementation of environmental management systems (EMS), will yield benefits that improve firm performance.

The relationship between EMS and statistical process control (SPC) is useful to consider. The early work of Feigenbaum (1951) and Juran (Juran, Gryna \& Bingham 1974) classified quality costs into four categories: prevention, appraisal, internal failure, and external failure. The same four categories can be used to describe environmental processes. Chandrashekar, Dougless and Avery (1999) analyzed these elements in terms of process quality and environmental effects, and observed a high level of correlation. This linkage of EMS and SPC lends conceptual support to the existence of an underlying relationship, such as the possibility that the effectiveness of one is positively moderated by the other.

Boudreau, Hopp, McClain, and Thomas (2003) discussed the benefits of SPC in terms of the ability of operators to identify process problems immediately and quantitatively - rather than waiting for a general inspection to be completed at the end of the process. After inspection justifies the rejection of a lot due to excessive defective items, the firm treats it as a waste. However, with the aid of SPC, defects can be identified in advance. This would reduce waste, and would be favorable for the environment while ultimately increasing operational efficiency.

"SPC can be used to monitor process emissions and prompt action when emissions are out of control or too close to the regulatory limits. Operators can rarely see the physical emissions caused by a process and hence cannot manage them carefully without having the real-time pollution data available that SPC provides" (Corbett \& Klassen, 2006). A capability index, which measures the extent to which the process is capable of meeting existing regulatory targets, can be viewed as a measure of the environmental quality of a process (Corbett \& Pan, 2002).

Corbett and Klassen (2006) indicate that while TQM defines defects in terms of customer requirements, the environmental perspective compels us to define defects in terms of a wider range of stakeholders. This gives rise to the view that environmental issues are a natural extension of quality management, and suggests that the tools and principles of quality management, including SPC, can enhance environmental performance. A strategic and tactical framework could be useful to support the extraction of synergistic benefits from EMS and SPC, with inimitable (and sometimes unexpected) resources emerging from environmental management practices improving firm performance.

It would be reasonable to expect the application of SPC to exert a positive interaction effect on the relationship between the implementation of an environmental management system and firm performance. This impact on the direction and strength of the effect of EMS implementation and firm performance would involve a moderating effect under the framework developed by Baron and Kenny (1986).

This leads to the following propositions.

Proposition 2a: Environmental management system implementation is positively associated with firm performance.

Proposition 2b: Statistical process control has a positive moderating effect on the relationship between environmental management system implementation and firm performance.

These propositions and the related conceptual framework are illustrated in Figure 3. 


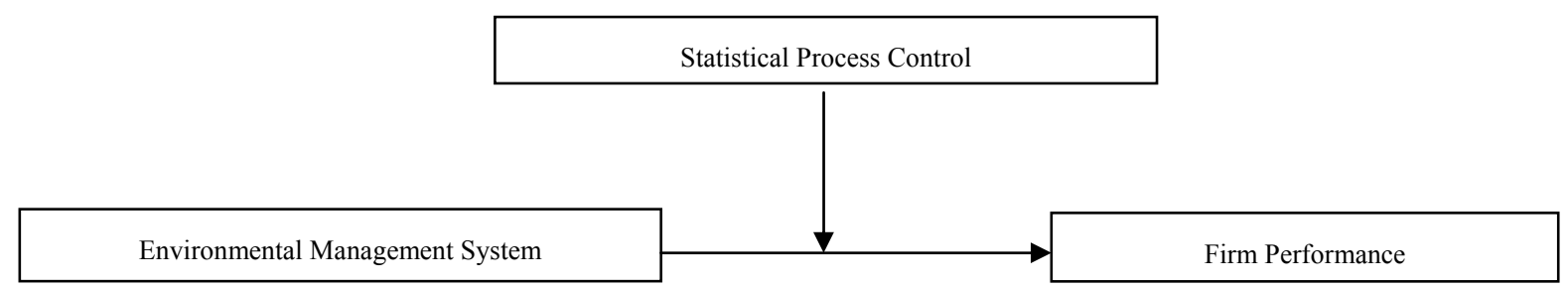

Figure 3. The moderating effect of statistical process control

EMS moderates the relationship between SPC and Firm Performance.

This gives rise to the expectation that firms relying more heavily on statistical process control to monitor and improve environmental management processes would tend to realize stronger firm performance effects than firms that place less reliance on SPC in such processes. A schematic illustration of the expected interaction effect of EMS implementation and SPC on firm performance is shown is Figure 4.

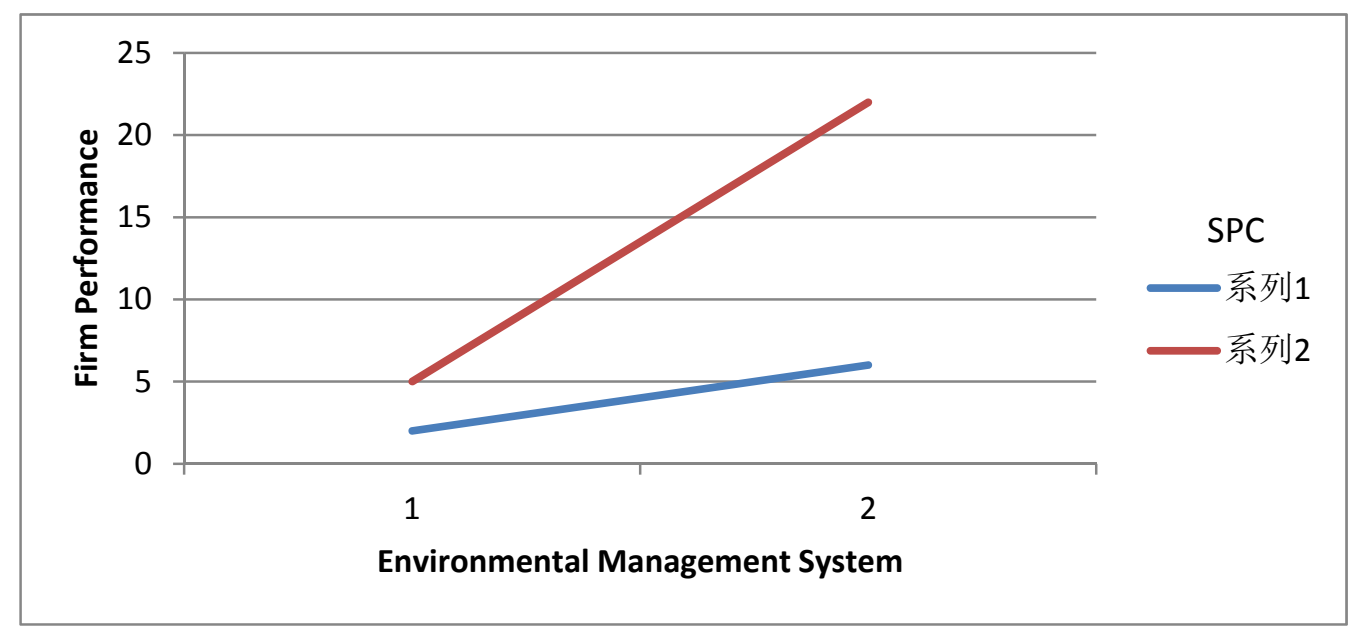

Figure 4. Interaction effect: EMS, SPC, and firm performance

A schematic of the expected interaction with SPC moderating the effect of EMS implementation on firm performance.

\section{Discussion and Future Research}

This article presents two conceptual frameworks regarding sustainable operations, quality management, and firm performance. In this section we discuss the theoretical contribution offered, and acknowledge limitations that can be addressed in future extensions of this research.

First and foremost, this paper offers theoretical frameworks and related propositions that can help researchers and practitioners understand the firm performance effects of environmentally responsible management practices, and the influence of specific factors related to quality management on the effectiveness of such practices. Research that links sustainability to firm performance is relatively rare, and the interaction effects of specific quality management practices on environmental management techniques has also been previously under-researched.

The theoretical frameworks presented here can be validated or refuted with empirical data. Propositions 1a and $1 \mathrm{~b}$ can be tested as hypotheses with DFE implementation identified by field studies or survey data, and quality innovation represented by ISO 9000 certification and/or the adoption of Six Sigma techniques. Propositions 2a and $2 \mathrm{~b}$ can be tested with EMS implementation signified by ISO 14000 certification, and the application of SPC to environmental management practices identified by field studies or survey data.

We would recommend the use of archival data from audited financial statements to empirically test the propositions developed in this paper with regard to firm performance. Our intent would be to adapt the 
framework offered by Jiang et al. (2006), which groups ratios related to operational performance in terms of efficiency, productivity, and profitability. This approach embraces statements made by Hendricks and Singhal (1997) and Jiang et al. (2006) on the preferability of using data from published financial statements rather than the perceptual opinions and self-reported evaluations of managers in survey responses to evaluate firm performance.

Our preferred firm performance measures are specified in Table 1. In some instances we have modified the formulas used by Jiang et al. (2006) for consistency with formulas that are commonly used in managerial accounting (see, for example Horngren, Datar, Foster, Rajan, \& Ittner, 2009).

Table 1. Firm performance metrics

\begin{tabular}{|c|c|}
\hline Metric Categories and Descriptions & Calculation Formulas \\
\hline \multicolumn{2}{|l|}{ 1. Cost efficiency } \\
\hline 1a. Selling, General \& Admin Expense / Sales & SG\&A / Sales \\
\hline 1b. Operating Expense / Sales & $(\mathrm{SG} \& \mathrm{~A}+\mathrm{COGS}) /$ Sales \\
\hline \multicolumn{2}{|l|}{ 2. Productivity } \\
\hline 2a. Asset Turnover & Sales / Average Total Assets \\
\hline 2b. Fixed Asset Turnover & Sales / Average PP\&E Net of Depreciation \\
\hline 2c. Inventory Turnover & COGS / Average Inventory \\
\hline 2d. Sales per Employee & Sales / Average Number of Employees \\
\hline \multicolumn{2}{|l|}{ 3. Profitability } \\
\hline 3a. Return on Assets & (Net Income / Average Total Assets) $\times 100 \%$ \\
\hline 3b. Net Profit Margin & (Net Income / Sales) × 100\% \\
\hline
\end{tabular}

The principal limitation of this research lies in its character as a conceptual study. The development of the frameworks presented here is supported by a deep survey of relevant literature, but extending this work with empirical studies will be necessary to confirm or refute the validity of the propositions embodied in these frameworks. Challenges in the empirical follow-up will involve the proper operationalization of constructs to support a high degree of external validity.

In addition to direct extensions of this research discussed in the preceding paragraphs, additional research methods such as case studies and action research projects will be useful in exploratory research. These follow-on studies can provide further insight on the use of quality management techniques with sustainable operations management initiatives to enhance firm performance.

\section{Conclusions}

Peer-reviewed research on sustainable operations has considered the relationship of environmental management to quality management from a broad-brush perspective, but relationships among specific practices in those two areas have been under-researched. This paper presents two conceptual frameworks for understanding relationships among specific environmental management practices, quality management practices, and firm performance. The first framework considers the mediating effect of quality innovation on the relationship between design for environment and firm performance. The second framework deals with the moderating effect of statistical process control on the relationship between environmental management systems and firm performance.

The concepts and relationships developed in this paper can be studied empirically to validate or refute these conceptual frameworks. We offer specific methodological suggestions for future empirical studies, and also identify avenues for future exploratory research on the relationships among specific environmental and quality management practices. We anticipate that the conceptual frameworks offered here will inform research in sustainable operations, and that empirical findings from such research will help practicing managers draw measurable firm performance advantages from environmental management initiatives.

\section{References}

Allenby, B. R. (1994). Integrating environment and technology: Design for environment. The Greening of Industrial Ecosystems. Washington, DC: National Academy Press. 
Baron, R. M., \& Kenny, D. A. (1986).The moderator-mediator variable distinction in social psychological research: Conceptual, strategic, and statistical considerations. Journal of Personality and Social Psychology, 51(6), 1173-1182. http://dx.doi.org/10.1037/0022-3514.51.6.1173

Beske, P., Land, A., \& Seuring, S. (2014). Sustainable supply chain management practices and dynamic capabilities in the food industry: A critical analysis of the literature. International Journal of Production Economics, 152(1), 131-143. http://dx.doi.org/10.1016/j.ijpe.2013.12.026

Boks, C., \& Stevels, A. (2007).Essential perspectives for design for environment: Experiences from the electronics industry. International Journal of Production Research, 45(18-19), 4021-4039. http://dx.doi.org/10.1080/00207540701439909

Boudreau, J., Hopp, W., McClain, J. O., \& Thomas, L. J. (2003). On the interface between operations and human resources management. Manufacturing \& Service Operations Management, 5(3), 179-202. http://dx.doi.org/10.1287/msom.5.3.179.16032

Brady, D. (2003). Will Jeff Immelt's new push pay off for GE? Business Week, 94-98.

Brundtland, G. H. (1987). Our Common Future. Geneva: World Commission on Environment and Development.

Buffa, E. S. (1980). Research in Operations Management. Journal of Operations Management, 1(1), 1-8. http://dx.doi.org/10.1016/0272-6963(80)90005-4

Calia, R. C., Guerrini, F. M., \& De Castro, M. (2009). The impact of six sigma in the performance of a pollution prevention program. Journal of Cleaner Production, 17(15), 1303-1310. http://dx.doi.org/10.1016/j.jclepro.2009.05.001

Chandrashekar, A., Dougless, T., \& Avery, G. C. (1999). The environment is free: The quality analogy. Journal of Quality Management, 4(1), 123-143. http://dx.doi.org/10.1016/s1084-8568(99)80099-6

Chase, R. B. (1980). A classification and evaluation of research in operations management. Journal of Operations Management, 1(1), 9-14. http://dx.doi.org/10.1016/0272-6963(80)90006-6

Chen, S. H., Yang, C.C., Lin, W. T., \& Yeh, T. M. (2008).Performance evaluation for introducing statistical process control to the liquid crystal display industry. International Journal of Production Economics, 111(1), 80-92. http://dx.doi.org/10.1016/j.ijpe.2006.12.055

Coddington, W. (1993). Environmental marketing: Positive strategies for researching the green customer. New York: McGraw-Hill.

Coleman, S. Y., Arunakumar, G., Foldvary, F., \& Feltham, R. (2001). SPC as a tool for creating a successful business measurement framework. Journal of Applied Statistics, 28(3/4), 325-334. http://dx.doi.org/10.1080/02664760120034063

Colledani, M., \& Tolio, T. (2009). Performance evaluation of production systems monitored by statistical process control and off-line inspections. International Journal of Production Economics, 120(2), 348-367. http://dx.doi.org/10.1016/j.jpe.2007.07.011

Comoglio, C., \& Botta, S. (2012). The use of indicators and the role of environmental management systems for environmental performances improvement: A survey on ISO 14001 certified companies in the automotive sector. Journal of Cleaner Production, 20(1), 92-102. http://dx.doi.org/10.1016/j.jclepro.2011.08.022

Corbett, C. J., \& Klassen, R. D. (2006). Extending the horizons: Environmental excellence as key to improving operations. Manufacturing \& Service Operations Management, $8(1), \quad 5-22$. http://dx.doi.org/10.1287/msom.1060.0095

Corbett, C. J., \& Pan, J. (2002). Evaluating environmental performance using statistical process control techniques. European Journal of Operations Research, 139(1), 68-83. http://dx.doi.org/10.1016/s0377-2217(01)00155-2

Dale, B. G. (2003). Managing quality. Malden Massachusetts: Blackwell Publishing.

Daly, H. E., \& Cobb, J. (1994).For the Common Good. Boston: Beacon Press.

Denton, D. K. (1991).Lessons on competitiveness: Motorola's approach. Production and Inventory Management Journal, 32(3), 22-25.

Dowell, G., Hart, S., \& Yeung, B. (2000). Do corporate global environmental standards create or destroy market value? Management Science, 46(8), 1059-1074. http://dx.doi.org/10.1287/mnsc.46.8.1059.12030 
Elkington, J. (1994). Towards the sustainable corporation: Win-win-win business strategies for sustainable development. California Management Review, 36(2), 90-100. http://dx.doi.org/10.2307/41165746

Elkington, J. (1997). Cannibals with Forks: The Triple Bottom Line of 21st Century Business. London: Capstone.

Ernzer, M., \& Wimmer, W. (2002). From environmental assessment results to design for environment product changes: An evaluation of quantitative and qualitative methods. Journal of Engineering Design, 13(3), 233-242. http://dx.doi.org/10.1080/09544820110108935

Feigenbaum, A. V. (1951). Quality Control: Principles, Practice and Administration. New York: McGraw-Hill.

Feigenbaum, A. V. (1983). Total Quality Control: Engineering and Management (3rd ed.). New York: McGraw-Hill.

Goh, T. N., Low, P. C., Tsui, K. L., \& Xie, M. (2003). Impact of six sigma implementation on stock price performance. Total Quality Management \& Business Excellence, 14(7), 753-763. http://dx.doi.org/10.1080/1478336032000090969

González-Benito, J., \& González-Benito, Ó. (2008). Operations management practices linked to the adoption of ISO14001: An empirical analysis of Spanish manufacturers. International Journal of Production Economics, 113(1), 60-73. http://dx.doi.org/10.1016/j.ijpe.2007.02.051

Guide Jr., V. D. R., \& Van Wassenhove, L. N. (2009). The evolution of closed-loop supply chain research. Operations Research, 57(1), 10-18. http://dx.doi.org/10.1287/opre.1080.0628

Handfield, R. B., Walton, S. V., Seegers, L. K., \& Melnyk, S. A. (1997). "Green” value chain practices in the furniture industry. Journal of Operations Management, 15(4), 293-315. http://dx.doi.org/10.1016/s0272-6963(97)00004-1

Hanna, M. D., \& Newman, W. R. (1995). Operations and environment: An expanded focus for TQM. International Journal of Quality \& Reliability Management, 125(5), 38-53. http://dx.doi.org/10.1108/02656719510089984

Hendricks, K. B., \& Singhal, V. R. (1997). Does implementing an effective TQM program actually improve operating performance? Empirical evidence from firms that have won quality awards. Management Science, 43(9), 1258-1274. http://dx.doi.org/10.1287/mnsc.43.9.1258

Hendricks, K. B., \& Singhal, V. R. (2001a). Firm characteristics, total quality management, and financial performance. Journal of Operations Management, 19(3), 269-285.

Hendricks, K. B., \& Singhal, V. R. (2001b). The long-run stock price performance of firms with effective TQM programs. Management Science, 47(3), 359-368. http://dx.doi.org/10.1016/s0272-6963(00)00049-8

Heras-Saizarbitoria, I., Molina-Azorín, J. F., \& Dick, G. P. M. (2011). ISO 14001 certification and financial performance: Selection-effect versus treatment-effect. Journal of Cleaner Production, 19(1), 1-12. http://dx.doi.org/10.1016/j.jclepro.2010.09.002

Horngren, C. T., Datar, S. M., Foster, G., Rajan, M. V., \& Ittner, C. (2009). Cost Accounting: A Managerial Emphasis (13th ed.). New York: Pearson.

International Standards Organization. (2014a). ISO9000 Quality Management. Retrieved from http://www.iso.org/iso/home/standards/management-standards/iso_9000.htm

International Standards Organization. (2014b). ISO 14000 Essentials. Retrieved from http://www.iso.org/iso/iso_catalogue/management_and_leadership_standards/environmental_management/i so14000

Jacobs, B. W., Singhal, V. R., \&Subramanian, R. (2010). An empirical investigation of environmental performance and the market value of the firm. Journal of Operations Management, 28(5), 430-441. http://dx.doi.org/10.2139/ssrn.1320721

Jiang, B., Frazier, G. V., \&Prater, E. L. (2006). Outsourcing effects on firms' operational performance. International Journal of Operations \& Production Management, 26(12), 1280-1300. http://dx.doi.org/10.1108/01443570610710551

Juran, J. M., Gryna, G., \& Bingham, R. S. (1974). Quality Control Handbook. New York: McGraw-Hill. 
King, A. A., \& Lenox, M. J. (2001). Lean and green? An empirical examination of the relationship between lean production and environmental performance. Production \& Operations Management, 10(3), 244-256. http://dx.doi.org/10.1111/j.1937-5956.2001.tb00373.x

King, A. A., \& Lenox, M. J. (2002). Exploring the locus of profitable pollution reduction. Management Science, 48(2), 289-299. http://dx.doi.org/10.1287/mnsc.48.2.289.258

Kitazawa, S., \& Sarkis, J. (2000). The relationship between ISO 14001 and continuous source reduction programs. International Journal of Operations \& Production Management, 20(2), 225-248. http://dx.doi.org/10.1108/01443570010304279

Klassen, R. D., \& McLaughlin, C. P. (1993). TQM and environmental excellence in manufacturing. Industrial Management \& Data Systems, 93(6), 14-22. http://dx.doi.org/10.1108/02635579310040924

Klassen, R. D., \& McLaughlin, C. P. (1996). The impact of environmental management on firm performance. Management Science, 42(8), 1199-1214. http://dx.doi.org/10.1287/mnsc.42.8.1199

Kleindorfer, P. R., Singhal, K., \& Van Wassenhove, L. N. (2005). Sustainable operations management. $\begin{array}{llll}\text { Production } \quad \text { and } & \text { Management, } & \text { 14(4), }\end{array}$ http://dx.doi.org/10.1111/j.1937-5956.2005.tb00235.x

Krajewski, L. J., Ritzman, L. P., \& Malhotra, M. K. (2010). Operations Management: Processes and Supply Chains (9th ed.). Upper Saddle River, New Jersey: Prentice Hall.

Laroche, M., Bergeron, J., \& Barbaro-Forleo, G. (2001). Targeting consumers who are willing to pay more for environmentally friendly products. Journal of Consumer Marketing, 18(6), 503-520. http://dx.doi.org/10.1108/eum0000000006155

Lenox, M., King, A., \& Ehrenfeld, J. (2000). An assessment of design-for-environment practices in leading US electronics firms. Interfaces, 30(3), 83-94. http://dx.doi.org/10.1287/inte.30.3.83.11669

Link, S., \& Naveh, E. (2006). Standardization and discretion: Does the environmental standard ISO 14001 lead to performance benefits? IEEE Transactions on Engineering Management, 53(4), 508-519. http://dx.doi.org/10.1109/tem.2006.883704

Linton, J.D., Klassen, R., \& Jayaraman, V. (2007). Sustainable supply chains: An introduction. Journal of Operations Management, 25(6), 1075-1082. http://dx.doi.org/10.1016/j.jom.2007.01.012

Lucier, G. T., \& Seshadri, S. (2001). GE takes six sigma beyond the bottom line. Strategic Finance, 82(11), 41-46.

Mannion, R. F. (1996). Enhancing corporate performance through quality-driven pollution prevention. National Productivity Review, 16(1), 25-32. http://dx.doi.org/10.1002/npr.4040160106

Matias, J. C. O. (1999). Normas de gestao da qualidadeambiental total. RevistaElectricidade, 370, 247-251.

Matias, J. C. O., \& Coelho, D. A. (2002). The integration of the standards system of quality management, environmental management and occupational health and safety management. International Journal of Production Research, 40, 3857-3866. http://dx.doi.org/10.1080/00207540210155828

McDermott, M. J. (1995). The global industrial flea market. Profiles Magazine, 59-62.

Melnyk, S. A., Sroufe, R. P., \& Calantone, R. J. (2003). A Model of site-specific antecedents of ISO 14000 certification. Production \& Operations Management, $12(3), \quad 369-385$. http://dx.doi.org/10.1111/j.1937-5956.2003.tb00209.x

Menon, A., \& Menon, A. (1997). Enviropreneurial marketing strategy: The emergence of corporate environmentalism as market strategy. Journal of Marketing, 61(1), 51-67. http://dx.doi.org/10.2307/1252189

Montabon, F., Melnyk, S. A., Sroufe, R., \& Calantone, R. J. (2000). ISO 14000: Assessing its perceived impact oncorporate performance. Journal of Supply Chain Management, 36(2), 4-16. http://dx.doi.org/10.1111/j.1745-493x.2000.tb00073.x

Oakland, J. S. (2003). Statistical process control. Burlington, Massachusetts: Butterworth Heinemann.

Ou, Y., Wu, Z., \& Tsung, F. (2012). A comparison study of effectiveness and robustness of control charts for monitoring process mean. International Journal of Production Economics, 135(1), 479-490. http://dx.doi.org/10.1016/j.ijpe.2011.08.026 
Pande, P. S., Neuman, R. P., \& Cavanaugh, R. R. (2000). The Six Sigma Way. New York: McGraw-Hill.

Pojasek, R. B. (2002). Combining quality tools with a traditional approach to pollution prevention. Environmental Quality Management, 12(1), 83-90. http://dx.doi.org/10.1002/tqem.10055

Porter, M. E., \& Van Der Linde, C. (1995). Green and competitive: Ending the stalemate. Harvard Business Review, 73(5), 120-134. http://dx.doi.org/10.1016/0024-6301(95)99997-e

Rusinko, C. A. (2005). Using quality management as a bridge to environmental sustainability in organizations. SAM Advanced Management Journal, 70(4), 54-60.

Saghaei, A., Najafi, H., \& Noorossana, R. (2012). Enhanced rolled throughput yield: A new six sigma-based performance measure. International Journal of Production Economics, 140(1), 368-373. http://dx.doi.org/10.1016/j.ijpe.2012.02.002

Samson, D., \& Terziovski, M. (1999). The Relationship between total quality management practices and operational performance. Journal of Operations Management, 17(4), 393-409. http://dx.doi.org/10.1016/s0272-6963(98)00046-1

Sarkis, J. (1998). Evaluating environmentally conscious business practices. European Journal of Operational Research, 107(1), 159-174. http://dx.doi.org/10.1016/s0377-2217(97)00160-4

Shafer, S. M., \& Moeller, S. B. (2012). The effects of six sigma on corporate performance: An empirical $\begin{array}{llll}\text { investigation. Journal of Operations } & \text { Management, 30(7/8), }\end{array}$ http://dx.doi.org/10.1016/j.jom.2012.10.002

Sower, V. E. (1993). SPC implementation in the plastic molding industry. Production \& Inventory Management Journal, 34(1), 41-45. http://dx.doi.org/10.1108/14635779610118687

Sroufe, R., \& Curkovic, S. (2008). An examination of ISO 9000:2000 and supply chain quality assurance. Journal of Operations Management, 26(4), 503-520. http://dx.doi.org/10.1016/j.jom.2007.06.006

Sroufe, R., Curkovic, S., Montabon, F., \& Melnyk, S. A. (2000). The new product design process and design for environment. International Journal of Operations \& Production Management, 20(2), 267-291. http://dx.doi.org/10.1108/01443570010304297

Swamidass, P. M., \& Majerus, C. (1991). Statistical control of manufacturing cycle time and project time: Lessons from statistical process control. International Journal of Production Research, 29(3), 551-563. http://dx.doi.org/10.1080/00207549108930088

Swink, M., \& Jacobs, B. W. (2012). Six Sigma adoption: Operating performance impacts and contextual drivers of success. Journal of Operations Management, 30(6), 437-453. http://dx.doi.org/10.1016/j.jom.2012.05.001

Vastag, G., \& Melnyk, S. A. (2002). Certifying environmental management systems by the ISO 14001 standards. International Journal of Production Research, 40(18), 4743-4763. http://dx.doi.org/10.1080/00207540210161632

Veroutis, A., \& Aelion, V. (1996). Design for environment: An implementation framework. Environmental Quality Management, 5(4), 55-68. http://dx.doi.org/10.1002/tqem.3310050408

Wiengarten, F., \& Pagell, M. (2012). The importance of quality management for the success of environmental management initiatives. International Journal of Production Economics, 140(1), 407-415. http://dx.doi.org/10.1016/j.ijpe.2012.06.024

Zhu, Q., \& Sarkis, J. (2004). The link between quality management and environmental management in firms of differing size: An analysis of organizations in China. Environmental Quality Management, 13(3), 53-64. http://dx.doi.org/10.1002/tqem.20004

$\mathrm{Zu}$, X., Fredendall, L. D., \& Douglas, T. J. (2008). The evolving theory of quality management: The role of six sigma. Journal of Operations Management, 26(5), 630-650. http://dx.doi.org/10.1016/j.jom.2008.02.001

\section{Copyrights}

Copyright for this article is retained by the author(s), with first publication rights granted to the journal.

This is an open-access article distributed under the terms and conditions of the Creative Commons Attribution license (http://creativecommons.org/licenses/by/3.0/). 